\title{
Strategi Dita Maharani Membentuk Personal Branding dalam Membangun Dita Maharani Language Academy di Instagram
}

\author{
Salsabila Afifa Hidayat ${ }^{1 *}$, Eko Harry Susanto \\ ${ }^{1}$ Fakultas Ilmu Komunikasi, Universitas Tarumanagara, Jakarta* \\ Email: sb.afifahidayat@gmail.com \\ ${ }^{2}$ Fakultas Ilmu Komunikasi, Universitas Tarumanagara, Jakarta \\ Email: ekos@fikom.untar.ac.id
}

Masuk tanggal: 15-12-2021, revisi tanggal : 06-01-2022, diterima untuk diterbitkan tanggal : 16-01-2022

\begin{abstract}
Nowadays, English has been a main concern for people. Besides the value of an English language as an universal language english language is a tool of communication. A very supported growth by a technology make some communication activities become easier with an Internet and social media. Within using internet and social media, we can make it as a branding in sharing and marketing about anything. In this research case will study about Dita Maharani, a person whose using social media to build her personal branding throughout Instagram. This case study will be approach by qualitative method by an intens interviewed and participated observered. The theories will be using are personal branding, interpersonal communications, and self-presentation. This research stated that Dita Maharani did some strategies and interpersonal communications in building her personal branding through Instagram until she has a credibility to get audience interested and want to join her class in Dita Maharani Language Academy (DMLA)
\end{abstract}

Keywords: interpersonal communications, personal branding

\begin{abstract}
Abstrak
Saat ini, Bahasa Inggris menjadi fokus utama bagi sejumlah orang. Selain dinilai sebagai bahasa universal, Bahasa Inggris juga dijadikan sebagai alat untuk berkomunikasi. Didukung dengan adanya teknologi yang berkembang pesat menjadikan kegiatan komunikasi menjadi lebih mudah dengan adanya internet dan media sosial Dengan memanfaatkan internet dan media sosial bisa dijadikan sebagai branding dalam sharing atau memasarkan apapun. Penelitian ini membahas Dita Maharani yang merupakan seseorang yang memanfaatkan media sosial untuk membangun personal branding lewat Instagram. Penelitian ini dikaji menggunakan metode kualitatif dengan melakukan wawancara yang cukup intens melalui virtual dan observasi partisipatif. Sejumlah konsep digunakan pada penelitian yaitu personal branding, komunikasi interpersonal dan teori presentasi diri. Hasil dari penelitian menyatakan bahwa Dita Maharani menerapkan strategi dan komunikasi antarpribadi dalam membentuk personal branding melalui Instagram hingga memiliki kredibilitas yang cukup dan dapat menarik audience untuk bergabung dengan sekolah Bahasa Inggrisnya di Dita Maharani Language Academy (DMLA)
\end{abstract}

Kata Kunci: komunikasi interpersonal, personal branding

\section{Pendahuluan}

Banyak manfaat yang kita dapat dari jejaring sosial. Selain jangkauannya tidak terbatas sehingga kita bisa berkomunikasi dengan siapa saja dan di mana saja, jejaring sosial juga biasa dimanfaatkan untuk kontrol sosial masyarakat terhadap 
pemerintah. Dengan berkembangnya zaman serta teknologi di era modern saat ini, keberadaan internet dan jejaring sosial sangat berpengaruh dalam kehidupan seharihari. Kehidupan manusia di dunia saat ini telah dikontrol oleh internet termasuk di Indonesia. Melansir dari situs web Wearesocial.com jumlah pengguna internet aktif masyarakat Indonesia mencapai 175.4 juta atau sebanyak $88 \%$ pada Januari 2020. Hal tersebut meningkat sebanyak $17 \%$ atau sekitar 25 juta pengguna aktif baru yang menggunakan internet dari tahun 2019 lalu.

Dengan adanya fasilitas internet, berbagai platform media bermunculan. Media sosial saat ini menjadi hal yang sangat krusial bagi manusia. Media sosial yang saat ini masih menjadi media yang paling dicari adalah Instagram. Instagram adalah aplikasi yang menjadi media untuk berbagi foto seputar aktivitas penggunanya yang memungkinkan mereka untuk berfoto dan memberi filter serta caption menarik lalu menyebarluaskannya di media sosial lainnya seperti Facebook, Twitter, dan lainnya. Saat ini Instagram juga dapat dijadikan sebagai media untuk membangun personal branding individu.

Bahasa merupakan alat untuk bisa berkomunikasi dengan manusia. Komunikasi tidak dapat dipisahkan dari setiap manusia karena dalam keseharian manusia selalu mengunakan sebagaian besar waktu untuk berkomunikasi dengan orang disekitarnya. Komunikasi merupakan cara untuk mengendalikan lingkungan fisik dan psikologis seseorang.

Dengan adanya penyebaran informasi tentunya harus dilakukan dengan berkomunikasi dengan cara yang benar. Menurut DeVito (dalam Maulana \& Gumelar, 2013) mendefinisikan komunikasi interpersonal sebagai penyampaian pesan oleh satu orang (komunikator) dan penerimaan pesan oleh orang lain (komunikan) atau sekelompok kecil orang, dengan berbagai dampaknya dan dengan peluang untuk memberikan umpan balik.

Komunikasi antarpribadi adalah komunikasi yang terjadi secara dialogis, dimana saat seorang komunikator berbicara maka akan terjadi umpan balik dari komunikan sehingga terdapat interaksi. Dalam komunikasi antarpribadi, baik komunikator maupun komunikan, keduanya aktif dalam proses pertukaran informasi yang berlangsung dalam suatu interaksi. Dengan adanya komunikasi interpersonal maka kepribadian seseorang akan terlihat. Hal ini akan terlihat dari bagaimana seseorang tersebut mempresentasikan dirinya saat melakukan proses komunikasi. Bullingham \& Vasconcelos (2013) mengatakan bahwa pernyataan dari studi dari Erving Goffman, presentasi diri merupakan sebuah analisis dari interaksi interpersonal dan upaya seseorang memproyeksikan visual sosok diri yang ingin ditampilkan dalam sebuah panggung yang menampilkan sisi depan dan belakang.

Menurut Haroen (2014), personal branding adalah penjelasan 3W yaitu tentang siapa anda yang sebenarnya (Who are you), apa yang telah anda lakukan sebelumnya (What have you done), dan apa visi misi anda kedepan (What will you do). Dengan demikian, personal branding adalah penjelasan atau proses komunikasi tentang karakter, kompetensi dan kekuatan anda (3K).

Menurut Erwin dan Tumewu (2015), personal brand adalah "Suatu kesan yang berkaitan dengan keahlian, perilaku maupun prestasi yang dibangun oleh seseorang baik secara sengaja maupun tidak sengaja dengan tujuan untuk menampilkan citra dirinya."

Dari pengertian di atas, dapat disimpulkan bahwa personal branding merupakan penjelasan atau proses komunikasi mengenai kepribadian, kemampuan, nilai-nilai, keahlian, perilaku, prestasi, keunikan dan bagaimana semua itu dapat 
menimbulkan persepsi positif dari masyarakat yang pada akhirnya persepsi tersebut dapat menjadi suatu identitas yang digunakan oleh orang lain dalam mengingat seseorang.

Dalam hal ini penulis meneliti mengenai komunikasi yang dilakukan oleh Dita Maharani pemilik akun Instagram Sekolah Bahasa Inggris Online DMLA (Dita Maharani Language Academy) mengenai cara berkomunikasi dengan orang lain melalui media sosial khususnya Instagram berdasarkan karakter atau sifat sosial yang ada pada pengikutnya (followers).

Penulis melakukan penelitian terhadap strategi apa saja yang dilakukan oleh Dita Maharani dalam membentuk personal branding di Instagram hingga dapat membangun Sekolah Bahasa Inggris Online.

\section{Metode Penelitian}

Dalam penulisan ini penulis menetapkan untuk menggunakan penelitian kualitatif, karena penelitian ini berhubungan langsung dengan manusia secara terperinci dan mendalam dan didasari melalui pengamatan. Menurut Sugiyono (2011), metode penelitian kualitatif adalah metode yang didasarkan pada filsafat postpositivisme, sedangkan untuk meneliti pada objek alamiah, dimana peneliti adalah sebagai instrument kunci, teknik pengumpulan data dilakukan dengan cara triangulasi (gabungan). Analisis data bersifat induktif atau kualitatif, dan hasil penelitian lebih menekankan makna daripada generalisasi.

Dalam penelitian ini, penulis memilih Dita Maharani sebagai subyek penelitian dan personal branding yang dibangunnya dalam membangun Insitusi Online Bahasa Inggris Dita Mahaarani Language Academy sebagai obyek penelitian. Metode pengumpulan data yang digunakan dalam penelitian ini yaitu wawancara mendalam, observasi pasif, dan studi kepustakaan. Seluruh data yang didapatkan melalui proses observasi oleh peneliti yang sebelumnya telah mengetahui Dita Maharani melalui Instagram dengan mengikuti (follow) akun tersebut sejak tahun 2016. Sejak saat itu, peneliti menjadi pengikut (follower) Dita Maharani dan mengamati aktivitas yang diunggah oleh Dita Maharani di Instagram-nya. Hingga akhirnya, Dita membuka enrollment class untuk berbagai macam kelas, lalu peneliti ikut mendaftar dan bergabung dalam Conversation Class pada Januari - Februari 2020 lalu. Dalam hasil observasi lebih lanjut dengan dilakukannya wawancara hanya bisa dilakukan melalui Zoom Meeting dan melalui What's App sebagai alat komunikasi.

Pada penelitian ini peneliti menggunakan triangulasi sumber. Peneliti melakukan pengumpulan data dengan melakukan wawancara secara langsung melalui Zoom Meeting dengan informan, data kepustakaan serta dokumentasi. Teknik triagulasi dengan sumber dinilai lebih mengutamakan efektifitas proses dan hasil yang diinginkan. Setelah itu peneliti membandingkan lalu menyimpulkan data yang diperoleh dari sumber yang berbeda agar data yang dihasilkan dapat valid dan teruji kebenarannya sesuai dengan makna dan menjawab permasalahan yang terjadi sesuai dengan triangulasi sumber.

\section{Hasil Temuan dan Diskusi}

Personal branding adalah suatu proses membentuk persepsi masyarakat terhadap aspek-aspek yang dimiliki oleh seseorang, diantaranya adalah kepribadian, 
kemampuan, atau nilai-nilai, dan bagaimana stimulus - stimulus ini menimbulkan persepsi positif dari masyarakat yang pada akhirnya dapat digunakan sebagai alat pemasaran. Ada tiga dimensi utama pembentuk personal branding (McNally \& Speak, 2002):

\section{Kompetensi atau Kemampuan Individu}

Kompetensi atau kemampuan dalam bidang tertentu harus dimiliki dan dikuasai oleh individu jika ingin membangun suatu personal branding. Seseorang dapat membentuk sebuah personal branding melalui sebuah media dan metode komunikasi yang disusun dengan baik. Personal Brand adalah sebuah gambaran mengenai apa yang masyarakat pikirkan tentang seseorang. Hal tersebut mencerminkan nilai-nilai, kepribadian, keahlian dan kualitas yang membuat seseorang berbeda dengan yang lainnya.

\section{Style}

Gaya merupakan kepribadian dari personal branding seseorang. Gaya merupakan bagian yang menjadikan diri seseorang unik di dalam benak orang lain. Gaya adalah cara anda berhubungan dengan orang lain. Seringkali kata-kata yang digunakan orang untuk menilai gaya seseorang mengandung suatu emosi yang kuat,

\section{Standar}

Standar personal branding seseorang sangat mempengaruhi cara orang lain memandang diri anda. Standar akan menetapkan dan memberikan makna terhadap kekuatan personal branding. Namun kuncinya adalah individu itu sendiri yang menetapkan standar, individu itu sendiri yang harus melakukan. Terkadang seseorang menetapkan standar yang terlalu tinggi dan terlanjur mengatakan pada orang lain bahwa kita mampu melakukan suatu hal dengan cepat dan dapat memperoleh hasil yang baik (agar kompetensi dan gaya personal branding kita kelihatan menarik di benak semua orang). Namun yang terjadi adalah sebaliknya, terkadang seseorang gagal untuk mencapai standar yang ditetapkan sendiri. Jadi dengan menggabungkan ketiga faktor tersebut, yaitu kompetensi, style dan standart, seseorang dapat mulai terus membangun dan mengembangkan reputasi dalam bidang khusus yang dipilih dan proses membangun reputasi adalah proses seumur hidup. Seseorang berharap semakin bertambah usia kita, semakin kuat "brand" atau reputasinya di masyarakat.

Hasil observasi dan wawancara dengan narasumber menunjukkan bahwa melalui Instagram, Dita memanfaatkan platform tersebut untuk membangun personal branding. Ia selalu menggunakan aplikasi Instagram sebagai tempat untuk sharing dan berinteraksi dengan audience atau followers. Semenjak berkerja di agensi, ia membangun personal branding sebagai content-traveler. Pada dasarnya ia memang mengunggah hal yang ia sukai, namun sejak mulai menjadi Instagram user, ia membangun platform tersebut sebagai media untuk membangun personal branding.

Awal mula ia suka menjelajah (travelling), mengunggah di Instagram seputar kegiatannya dalam menjelajahi berbagai tempat. Tidak sampai disitu, Dita akhirnya mencoba menjelajahi hal lain, yaitu bidang kecantikan (beauty). Ia cukup sering berbagi informasi seputar beauty essentials dan lifestyle. Ia cukup percaya diri serta yakin bahwa dirinya menggunakan aplikasi Instagram sebagai wadah yang tepat untuk ia bisa berbagi mengenai hal yang ia suka, namun ia masih ragu dalam 
memutuskan branding apa yang tepat untuk dirinya agar dapat dikenal dengan baik oleh followers.

Setelah mulai mengajar di tahun 2016, akhirnya ia menetapkan untuk membangun personal branding sebagai guru Bahasa Inggris yang juga memiliki kehidupan sendiri. Ia menyatakan bahwa, personal branding yang sudah ia berusaha untuk bangun dari awal sebagai guru merupakan ketulusan dari hatinya. Pada saat ia mengajar dirinya merasa bahwa setiap kata yang terucap dari mulutnya bermakna.

Sebelumnya, Dita Maharani memang memberlakukan cara mengajarnya dengan dua sistem, secara offline dan online. Dari sistem offline tersebut, ia masih menggunakan nama Lingua Business English sebagai nama institusi. Namun, saat pandemi datang, Dita Maharani memutuskan untuk melakukan rebranding dan memakai nama dirinya sendiri menjadi Dita Maharani Language Academy (DMLA) dan mengubah sistem pembelajaran menjadi sepenuhnya kelas online (full online class).

Dalam membangun sebuah institusi edukasi untuk Bahasa Inggris online sendiri, Dita Maharani memikirkan secara matang untuk program apa saja yang akan ia sajikan untuk para muridnya yang tentunya itu harus berbeda dengan kompetitor institusi edukasi Bahasa Inggris online maupun offline lainnya. Beberapa program yang ia tawarkan antara lain adalah General English, Conversation, Business English, IELTS dan TOEFL.

Menurut Susanto (2013), dinamika mencari informasi dapat dilihat ketika masyarakat mendengar dan menyaksikan peristiwa yang menyangkut dirinya, kelompok, atau komunitasnya. Hakikatnya, mereka mencari informasi dari sumber yang dikenal atau mudah diakses dan bersifat Multi Step Flow dengan berbagai variasi dalam penyebaran pesan dari sumber informasi kepada khalayak. Tahap awal, pencarian informasi sering dilakukan dalam komunikasi antarpribadi, yang merupakan proses pertukaran makna antar orang-orang yang saling berkomunikasi. Individu memiliki pemahaman dan makna pribadi dalam setiap hubungan dimana dia ada didalamnya.

Sejatinya, bahasa $i b u$ di Indonesia adalah Bahasa Indonesia. Namun, Bahasa Inggris sudah menjadi suatu kepentingan untuk berkomunikasi. Terlebih pada era globalisasi menuntut masyarakat bisa beradaptasi dengan cepat.

Dalam mengajar, Dita Maharani merasakan adanya komunikasi secara interpersonal antara guru dan murid, begitu pun sebaliknya. Menurut Dita Maharani, dalam proses ngajar-mengajar sangat diperlukan interaksi serta komunikasi yang digunakan juga harus mendalam. Dalam mempresentasikan dirinya, Dita Maharani jelas ingin menampilkan bahwa dirinya sebagai pengajar atau pendidik mempunyai kehidupan sendiri yang sebenarnya sangat relevan dengan murid-muridnya. Ia ingin menunjukkan bahwa ia adalah manusia biasa yang juga pasti membuat kesalahan. Salah satu strategi yang sangat ia pertahankan untuk dapat menjaga cara mengajarnya adalah dengan berkomunikasi. Dita percaya bahwa setiap orang memiliki latar belakang yang berbeda, maka dari itu mereka pun memiliki kebutuhan yang berbeda juga. Dita selalu menerapkan kepada setiap muridnya untuk take and give sehingga nantinya akan meghasilkan win-win solution diantara keduanya. 


\section{Simpulan}

Penulis merangkum beberapa kesimpulan yang menjadi hasil dari penelitian penulis sebagai berikut:

1. Personal branding yang dilakukan di akun pribadi Instagram memiliki dampak untuk institusi yang didirikan oleh seseorang. Dalam hal ini Dita Maharani dan pendidikan Bahasa Inggris online Dita Maharani Language Academy.

2. Adanya penerapan komunikasi mengenai keterbukaan, adanya rasa empati, suportif, positif dan merasa adanya kesetaraan antara ia dengan setiap murid yang diajarkannya.

3. Aplikasi Instagram menjadi platform yang menguntungkan untuk berbagi informasi dalam membangun personal branding yang membuat ia dikenal menjadi guru Bahasa Inggris walaupun menempuh proses perjalanan yang sangat panjang.

4. Strategi untuk membangun Dita Maharani Language Academy agar tetap bertahan dan stabil adalah dengan melakukan penelitian untuk mempunyai program english di DMLA yaitu General English, Conversation, Business English, hingga IELTS dan TOEFL. Membentuk tim internal yang terdiri dari Head Administration, Social Media Officer, dan penambahan guru, serta membentuk short dan long-term planning agar DMLA tetap mempunyai tujuan dan inovasi dibidang pendidikan Bahasa Inggris.

\section{Ucapan Terima Kasih}

Penulis mengucapkan terima kasih kepada seluruh pihak yang telah mendukung secara mental serta emosional dan membantu penulis selama proses penelitian berlangsung sampai dengan terbitnya jurnal penelitian ini.

\section{Daftar Pustaka}

DeVito, Joseph A. (2011). Komunikasi Antar Manusia. Tangerang Selatan: Karisma Publishing Group.

Heroen, Dewi. (2014). Personal Branding: Kunci Kesuksesan Dalam Berkipra. Jakarta: Gramedia Pustaka Utama.

McNally, D., dan Speak, K.D. (2002). Be Your Own Brand. San Fransisco: Berret Koehler Publisher.

Rarasati, D. B., Hudaniah, H., \& Prasetyaningrum, S. (2019). Strategi presentasi diri pengguna instagram ditinjau dari tipe kepribadian. Jurnal Ilmiah Psikologi Terapan, 7(2), 235-251.

Soegiyono. (2011). Metode Penelitian Kuantitatif, Kualitatif dan R\&D. Bandung: Alfabeta.

Susanto, Eko Harry. (2013). Komunikasi Politik: Pesan, Kepemimpinan dan Khalayak. Jakarta: Mitra Wacana Media.

Stevani, dan Widyatmoko. (2017). Kepribadian dan Komunikasi Susi Pudjiastuti dalam Membentuk Personal Branding. Jurnal Komunikasi 9(1) 65-73.

Tumewu, Becky., dan Erwin Parengkuan. (2015). Personal Brand Inc. Jakarta: Gramedia Pustaka Utama. 